\title{
Microorganisms Photocatalytic Inactivation on Ag3P04 Sub-microcrystals Under WLEDs Light Source
}

\section{João F Cruz-Filho}

Universidade Estadual do Piauí

\section{Tadeu M.S. Costa}

Universidade Estadual do Piauí

Maciel S Lima

Universidade Estadual do Piauí

Luis F.G. Nolêto

Universidade Federal do Piauí-UFPI

\section{Carla C. S. Bandeira}

cUniversidade Federal do $A B C$

\section{Francisca L Lima}

Universidade Estadual do Piauí

Geraldo Eduardo da Luz Júnior ( $\nabla$ geraldoeduardo@gmail.com )

Universidade Estadual do Piauí, Fundação Universidade Estadual do Piauí. https://orcid.org/00000003-4950-6742

\section{Original Research Full Papers}

Keywords: Ag3P04, microorganism inactivation, WLED, photocatalytic inactivation

Posted Date: February 2nd, 2021

DOI: https://doi.org/10.21203/rs.3.rs-169954/v1

License: (a) (1) This work is licensed under a Creative Commons Attribution 4.0 International License. Read Full License

Version of Record: A version of this preprint was published at Journal of Inorganic and Organometallic Polymers and Materials on February 11th, 2021. See the published version at https://doi.org/10.1007/s10904-021-01930-5. 


\title{
Microorganisms photocatalytic inactivation on $\mathrm{Ag}_{3} \mathrm{PO}_{4}$ sub- microcrystals under WLEDs light source
}

\author{
J.F. Cruz-Filho ${ }^{a}$, T.M.S. Costa ${ }^{a}$, M.S. Lima ${ }^{a}$, L.F.G Nolêto ${ }^{b}$, Carla C. S. Bandeira ${ }^{c}$, F.L. \\ Lima $^{\mathrm{d}}$, G.E. Luz Jr. ${ }^{\mathrm{a}, \mathrm{b}^{*}}$ \\ aPPGQ-GERATEC, Universidade Estadual do Piauí, Rua: João Cabral, N. 2231, P.O. Box 381, 64002- \\ 150, Teresina-PI, Brazil \\ ${ }^{\mathrm{b}}$ PPGQ-DQ, Universidade Federal do Piauí-UFPI, Petrônio Portela, 64049-550 Teresina, PI, Brazil \\ ${ }^{c}$ Universidade Federal do ABC, Campus Santo André - Bloco B Av. dos Estados, 5001 - Bairro Bangu - \\ Santo André/SP, Brazil - CEP: 09210-580. \\ ${ }^{d}$ Departamento de Biologia, Labmicro, Universidade Estadual do Piauí, Rua: João Cabral, N. 2231, \\ 64002-150, Teresina-PI, Brazil
}

\section{Abstract}

In this article, we report the silver orthophosphate $\left(\mathrm{Ag}_{3} \mathrm{PO}_{4}\right)$ photocatalytic inactivation properties on strains Gram-positive Saprophyte B. subtilis, a diploid fungus Candida albicans and Gram-negative Pseudomonas aeruginosa, using as irradiation source white-light-emitting diodes (WLEDs) with luminous flux ( $\Phi$ v) of $1.3 \times 10^{3}$ Lumens and relative power density of $15 \mathrm{~mW} \mathrm{~m} \mathrm{~m}^{-2}$. Microorganisms death curves and the kinetic constants $\left(\mathrm{K}_{\mathrm{d}}\right)$ indicated that the inhibitory effect of the $\mathrm{Ag}_{3} \mathrm{PO}_{4}$ under WLEDs irradiation is well pronounced to $C$. albicans $\left(6.6 \times 10^{-2} \mathrm{~min}^{-1}\right)$ in relation to $P$. augenosas $\left(4.6 \times 10^{-2} \mathrm{~min}^{-1}\right)$ and $B$. subitilis $\left(2.5 \times 10^{-2} \mathrm{~min}^{-1}\right)$. Decimal reduction time $\left(D_{\mathrm{t}}\right)$ were $34.4 \mathrm{~min}$ to $C$. albicans, $50.1 \mathrm{~min}$ P. augenosas and $92.1 \mathrm{~min}$ to B.subitilis The micrographs obtained by scanning electron microscopy with field emission gun (SEM-FEG) demonstrated that there was cell wall permeability and consequently total rupture in the $C$. albicans, suggesting the lipid peroxidation phenomenon and protein oxidation promoted by the presence of reactive oxygen species (ROS). Furthermore, it was observed the $\mathrm{A}_{\mathrm{g} 3} \mathrm{PO}_{4}$ when irradiated by WLEDs demonstrates important sporicidal activity in related to $B$. subtilis, promoting the endospore wall rupture. 
Keywords: $\mathrm{Ag}_{3} \mathrm{PO}_{4}$; microorganism inactivation; WLED; photocatalytic inactivation.

\section{Introduction}

Freshwater treatment for human consumption has become one of the greatest challenges in the world. This problem around the potability of water is progressively becoming worse than its scarcity has become a reality around the world [1]. Every year, thousands of people became ill due to the consumption of water contaminated by potentially pathogenic agents, such as: protozoa, bacteria and viruses that use water as a transmission vehicle [2]. Furthermore, it is important to note that major of these pathogens are closely related to malnutrition by the simple fact that intestinal infections and diarrheal diseases are caused by aquatic bacteria and enteric viruses develop a bad digestion in the contaminated individuals, especially children [3,4]. In developing countries, diarrhea causes more than 1.5 million deaths annually in children under the age of 5 years [4,5]. Furthermore, recurrent diarrheal episodes and malnutrition in infancy impair growth and development [6]. Another problem with regard to water portability is the proliferation of cyanobacteria or blue-green algae [7-9]. These microorganisms, in addition to providing hypoxic codes due to excessive oxygen consumption in the environment, promote contamination by secondary metabolites [10]. Under favorable nutrient and light conditions, these microorganisms produce a specific group of toxins known by cyanotoxins that have many detrimental effects on human, animal and environmental health [11-13]. The microcystin, class of toxins produced by certain cyanobacteria, are very stable, water-soluble end rapidly absorbed by the human body, resulting in cell necrosis, bleeding and death [7].

Conventional technologies used for disinfection of unportable water include chlorination, ozonization, and artificial UV radiation [14], being the first one of the 
widely used method [15]. However, the literature reports that is chlorine dissolved in water, when in contact with natural organic matter, produces potentially mutagenic and carcinogenic substances[16-20].

In response to the search for safe and efficient techniques, photocatalysis, due to its potential for converting solar energy to pollutant degradation, has attracted the attention of researches due to the possibility of developing advanced "green" oxidation technologies, being used in studies aimed at water disinfection [21-28]. Besides, it shows benefits in relation to ozonization and disinfection of water by UV irradiation, which, although they are promising [29-31], they are substantially complex techniques due to the risk of formation of potentially harmful byproducts [32-35]. Furthermore, the disinfection by UV radiation generally results in microbial regeneration after treatment is completed [36,37].

In the search for alternative methods of water disinfection recent studies have shown that a large class of semiconductors have shown important bactericidal activity against clinically relevant pathogens, especially compounds containing silver, zinc, copper and titanium in composition [38-42].

In this context, studies about the bacterial inactivation process have been carried out mainly to substantiate and ascertain the efficacy of new composites besides to outline likely mechanisms of photocatalytic disinfection [43-45]. Researches developed by Matsunaga et al. it has been demonstrated that the production process is closed and passed by the degradation of Coenzyme A by the reactive oxygen species (ROS) such as $\mathrm{O}_{2} \bullet-,{ }^{1} \mathrm{O}_{2}, \bullet \mathrm{OH}, \mathrm{H}_{2} \mathrm{O}_{2}$ and $\bullet \mathrm{HO}_{2}$ generated during the photocatalytic reaction that are in inhibition of the respiratory activity of the microorganism, thus leading to death [46]. Manes et al. reinforced that a microorganism exposed to ROS undergoes peroxidation of the phospholipid component of the cell wall leading to its rupture [47]. 
Concomitantly, Kikuchi et al. evaluated the role of ROS in the inhibitory process and proposed that the antimicrobial activity is a cooperative effect of all intermediates of ROS formed during the reaction process [48]. In addition, the contribution of the material to the mechanism of bactericidal activity though formation of oxidative species vary with: size [49-51], shape[5,51] and heterogeneity of the compound [52,53]. However, non ROS-mediated antibacterial activity, for example: cation dissolution, internalization of nanostructure [5,50-52,54] and interruption of cell transduction energy [50] also contribute to bactericidal activity.

Works involving $\mathrm{Ag}_{3} \mathrm{PO}_{4}$ silver orthophosphate have been expressive mainly due to their excellent properties optical, semiconductor [55-62], photocatalytic and antimicrobial [63-66] The particle size [57,67-70], synthesis methods[61,71-73], effect of the localized surface plasmon resonance (LSPR) induced by metallic nanoparticles $[68,74,75]$, as well as the morphology $[56,76,77]$ directly interfere in photocatalytic and biologic $\mathrm{Ag}_{3} \mathrm{PO}_{4}$ properties [78-80]. Moreover, $\mathrm{Ag}_{3} \mathrm{PO}_{4}$ presents high instability when irradiated, which impairs its use in photocatalys with conventional light sources [62,81]. In this perspective, the search for new configuration regarding the light source of the photocatalytic reactors must also be evaluated, as related in our recent work [81].

Conventional reactors, such as ultraviolet light emitted by mercury vapor lamps or emitted by xenon lamps, have been used effectively in inactivation of microorganisms such as bacteria, viruses and fungi. However, the disadvantages that these sources show are the possibility of contamination by mercury residues, short equipment life [82].

In contrast, since the blue LED emergence based on the AlInGAN and subsequently the construction of the white-light-emitting diodes (WLEDs) [83-85], these devices have attracted the attention of researchers due to the possibility of building compact, versatile photocatalytic reactors and design flexibility with regard to energy efficiency, economy, 
long relative life expectancy, enhanced luminosity and desired wavelength light adjustment.[4,36,86-88].

Based on that, this work aimed available the photocatalytic inactivation effects of $\mathrm{Ag}_{3} \mathrm{PO}_{4}$ sub-microcrystals, irradiated by a WLEDs arrangement, over the microorganism strains: Gram-positive Saprophyte B. subtilis, a diploid fungus Candida albicans and Gram-negative Pseudomonas aeruginosa.

\section{Materials and methods}

\subsection{Materials}

Sodium hydrogen phosphate $\left(\mathrm{Na}_{2} \mathrm{HPO}_{4}\right)$ and Silver nitrate $\left(\mathrm{AgNO}_{3}\right)$, were purchased from Sigma-Aldrich. The deionized water was obtained in the Purelab Option-Q Elga model DV-25 deionizer. For the preparation

of the culture medium was used the Müeller Hinton Agar of the Difcon ${ }^{\mathrm{TM}}$. All reagents used in this work were analytical grade.

\subsection{Synthesis and characterizations of $\mathrm{Ag}_{3} \mathrm{PO}_{3}$ microcrystals}

$\mathrm{Ag}_{3} \mathrm{PO}_{4}$ sample was prepared by the precipitation method. At first, $76.4 \mathrm{mg}$ of $\mathrm{AgNO}_{3}$ and $21.3 \mathrm{mg}$ of $\mathrm{Na}_{2} \mathrm{HPO}_{4}$ was dissolved in $3 \mathrm{ml}$ and $1 \mathrm{ml}$ of deionized water, respectively. The solutions were sonicated for $10 \mathrm{~min}$ and gradually diluted in deionized water to a volume of $500 \mathrm{ml}$. The solution was kept protected from ambient light; it being noted that the temperature varied naturally from $4{ }^{\circ} \mathrm{C}$ to $18{ }^{\circ} \mathrm{C}$ the $\mathrm{pH}$ remained around 6.5. After $72 \mathrm{~h}$ the deposited powder was oven dried at $100{ }^{\circ} \mathrm{C}$ for $6 \mathrm{~h}$. Sample of the $\mathrm{Ag}_{3} \mathrm{PO}_{4}$ prepared was thermally treated in a muffle furnace at $150{ }^{\circ} \mathrm{C}$ for $6 \mathrm{~h}$, with no air flow. The synthesized powder was stored in appropriate amber vials. 
The detailed synthesis procedure and characterization (XRD, XPS, UV-Vis, FTIR, MICRO-Raman and SEM-FE) of the $\mathrm{Ag}_{3} \mathrm{PO}_{4}$ were described in our recently work [81].

\subsection{Photocatalytic inactivation tests}

Photocatalytic inactivation tests were carried out using three microbial strains were used a Gram-positive Saprophyte (B. subtilis ATCC 6633), a diploid fungus (Candida albicans ATCC 10231), and Gram-negative (P. aeruginosa ATCC 27853) provided by Fiocruz. The microorganisms were grown in Mueller- Hinton agar $(\mathrm{MH})$ at $37^{\circ} \mathrm{C}$ for 24 h.

In general, for photocatalytic inactivation tests, $25 \mathrm{mg}$ of $\mathrm{Ag}_{3} \mathrm{PO}_{4}$ were dispersed in 25 $\mathrm{ml}$ of suspensions contends $\simeq 10^{5}$ colony-forming units per milliliter $\left(\mathrm{CFU} \mathrm{mL} \mathrm{m}^{-1}\right.$ ) [89], in buffer of the $\mathrm{MH}$ and kept under magnetic stirring at $35.5^{\circ} \mathrm{C}$ in a glass cell, at a distance of $6 \mathrm{~cm}$ from the irradiation source. Before testing, all glassware was sterilized in autoclave at $121^{\circ} \mathrm{C}$ for $30 \mathrm{~min}$.

The irradiation source used was a homemade reactor shown in details in a recent work of our group [81]. It is constituted by an arrangement of visible light emitting diodes (WLEDs) with luminous flux $(\Phi \mathrm{v})$ of $1.3 \times 10^{3}$ Lumens and relative power density of $15 \mathrm{~mW} \mathrm{~m}^{-2}$

In order to follow the tests over time, aliquots of $1 \mathrm{~mL}$ of the treated microbiological suspension were decanted and diluted in aqueous $\mathrm{NaCl}$ solution $(0.09 \%)$ to adjust the microbiological concentration, in order to ensure that the growing colonies were counted accurately and ease. To quantify the antimicrobial results during the irradiation time, $100 \mu \mathrm{L}$ of the treated solution was spread on agar plate and the colonies were counted to determine the curve dearth curve after incubation at $35 \pm 2{ }^{\circ} \mathrm{C}$ for $24 \mathrm{~h}$. It is 
worth noting that a blank test was performed using phosphate in solution containing microorganisms in the dark.

With the purpose of accompanying the injury suffered by the microorganisms during the $\mathrm{Ag}_{3} \mathrm{PO}_{4}$ photoactivity under WLEDs irradiation through micrographs obtained by SEM-FEG. Aliquots of $100 \mu \mathrm{L}$ of the reaction solution were collected in the time of the photocatalytic process and dispersed in aluminum foil, previously cleaned with isopropyl alcohol. The aluminum foils were kept in Petri plates coated with tissue paper embedded in formaldehyde solution (10\%) for $20 \mathrm{~min}$. To assess the photocatalytic inactivated effect, it was used the level of inactivation of microorganisms, which is generally analyzed by the inactivation effect [90], described below:

$$
-\log \left(N / N_{0}\right)=k t
$$

Where $N$ is the concentration of cells at time $t, N_{0}$ the concentration of cells in $t=0$ (initial) and $k t$ the inactivation rate.

Beyond the level of inactivation of microorganisms it was also used the decimal reduction time $\left(D_{\mathrm{t}}\right)$, corresponding to the time interval required to provide a decimal logarithm $\left(\log 10^{10}\right)$ within a defined set of conditions a $90 \%$ reduction in the initial viable bacterial population at a given temperature [91]. The decimal reduction time was obtained by equation (2).

$$
D_{t}=\left(2.303 / k_{t}\right)
$$

Were $k_{t}$ is the inactivation rate and 2.303 equals the natural logarithm of 10 .

\section{Results and discussion}

\subsection{Photocatalytic inactivation}


The photocatalytic inactivation results were shown in Fig.1. The inactivation curves demonstrate that $\mathrm{Ag}_{3} \mathrm{PO}_{4}$ inhibitory effect on the microorganisms under study improved significantly when subtracted from the WLEDs irradiance relative to white (no light effect). Inactivation profile of the fungus $C$. albicans, $P$. auginosas and B. subtilis presented first-order pseudo-kinetic behavior.

As shown in Fig. 1(a-c), bacterial inactivation occurred while the photocatalyst irradiation by WLEDs continued but the viability numbers in the control soon reached the initial values when placed in the dark.

According to the death curve and the kinetic constants $\left(K_{d}\right)$ (Fig. 2) obtained during the study effect, the inhibitory effect of the $\mathrm{Ag}_{3} \mathrm{PO}_{4}$ under irradiation WLEDs is well pronounced under the $C$. albicans strain $6.6 \times 10^{-2} \mathrm{~min}^{-1}$ in relation to B.subitilis and $P$. augenosas strain $2.5 \times 10^{-2} \mathrm{~min}^{-1}$ and $4.6 \times 10^{-2} \mathrm{~min}^{-1}$ respectively. The values of the $D_{t}$ obtained were: $34.4 \mathrm{~min}$ for $C$. albicans strain, $50.1 \mathrm{~min}$ for $P$. augenosas strain and 92.1 min for B.subitilis. The higher $D_{t}$ value for B.subitilis strains, may be linked to the ability of this microorganism to produce endospores as resistance form.

The main difference between the groups of microorganisms is the wall thickness that ranges from 20 to $80 \mathrm{~nm}$ for Gram-negative and 1.5 to $10 \mathrm{~nm}$ for Gram negative bacteria. In addition, only bacteria Gram negative have membrane [92]. However, each type of microorganism, as well as each species and lineage of the same group of organisms, has its own resistance to physical-chemical factors such as water content in the environment, $\mathrm{pH}$ and temperature, besides factors such as antibacterial concentration and media composition which should also be taken into account $[93,94]$. Therefore, only the relative sensitivity between Gram-negative and Gram-positive does not explain the results obtained much less in relation to the composition of the cell wall [95]. 
In order to observe cellular morphology changes, C. albicans (Fig. 3) and B. Subtilis cells (Fig. 5) were analyzed by SEM-FEG in different times of photocatalytic inactivation tests.

Fig. 3a shows a typically healthy basal cell of $C$. albicans, and cell structure in the form of a preserved elliptic (inset Fig.3a). From 10 to 60 min after the photocatalytic process start, the elliptical shape decreased and the cell structure became an atypical morphology, as shown in Fig. $3 \mathrm{~b}$ and Fig. 3c, but the membrane still retained its relative integrity. At $120 \mathrm{~min}$, there was a membrane cell disruption (Fig.3d and inset). In addition, it was observed the leakage of the cytoplasmic content through the cell wall (Fig. 3e), and a reduction in C. albicans cell size during the test, as shown in Fig. 4.

This behavior of C. albicans cells during the photocatalytic inactivation test may suggest that $\mathrm{Ag}_{3} \mathrm{PO}_{4}$ crystals, when irradiated by WLEDs, can promote the formation of reactive oxygen species (ROS) that cause the oxi-reduction of protein and lipid structures in cellular membrane, denaturing it and allowing the subsequent extravasation of cellular content, as shown in Fig. 3e.

The phenomena of lipid and protein oxidation causes instability in the normal potential of membrane, lipid fluidity and membrane dynamics, which in turn are essential for cell survival, as they participate in important functions such as: biochemical reactions, nutrient transport, protein secretion and permeability [96-98] Besides, the membrane damage causes not only important ions, such as potassium-bacterial cells, to leak [99103], but also the extravasation of cytoplasmic material that affects cell viability [104].

Fig. 5 shows a typically healthy basal cell of $B$. subitilis, and cell structure in the form of a preserved stick. 10 min after the start of the photocatalytic process, as shown in Fig. $6 \mathrm{~b}$, the stick shape shrank and the cell structure became a typical morphology. However, the layer still retained its relative integrity. At $20 \mathrm{~min}$, there was the rupture of the cell 
wall and the release of endospores, which is due to the ability of B. subtilis to form resistant endospores under adverse environmental conditions for bacterial growth as both physical and chemical agents [105-107]. Therefore, as soon as the environment becomes favorable, these spores can reproduce again and multiply. This B. subtilis behavior explains the low reduction in the number of colonies in the experiment where there was the presence of the photocatalyst in a darkroom. However, as shown in the fig. 5d, after $60 \mathrm{~min}$, the $\mathrm{Ag}_{3} \mathrm{PO}_{4}$ exhibited sporicidal activity on $B$. subtilis in the form of resistance with the consequent rupture of the endospore wall.

By being able to absorb visible light, $\mathrm{E}_{\mathrm{BG}}=2.15 \mathrm{eV}$ [81], $\mathrm{Ag}_{3} \mathrm{PO}_{4}$ is photoexcited in a large part of the light spectrum emitted by the arrangement of WLEDs, which promotes the electron from the valence band (VB) to the conduction band (CB) and thus forming the pair $\mathrm{e}^{-/ \mathrm{h}^{+}}$(Equation 1) $[77,108,109]$. In addition, the electrons transported to the surface of the semiconductor reacted with the oxygen dissolved in the liquid interface forming the superoxide $\left({ }^{\bullet} \mathrm{O}_{2}^{-}\right)$(Equation 2) together with the $\left(\mathrm{h}^{+}\right)$, also allocated on the semiconductor surface, to participate mainly in the process of heterogeneous photocatalysis in which it is used $\mathrm{Ag}_{3} \mathrm{PO}_{4}$ as active catalytic site [110-113]. It should be noted that both ${ }^{\bullet} \mathrm{O}_{2}^{-}$how much $\mathrm{h}^{+}$can participate in parallel reactions giving rise to hydroxyl radicals $\left({ }^{\bullet} \mathrm{OH}\right)$ (Equations 3-5 and 6,7, respectively), which also actively participate in microbial inhibition. The main reactions involved in the process are represented in equations (1-7) [83]:

$$
\begin{aligned}
& \mathrm{Ag}_{3} \mathrm{PO}_{4}+h \mathrm{v} \longrightarrow \mathrm{Ag}_{3} \mathrm{PO}_{4}+\mathrm{h}^{+}(\mathrm{VB})+\mathrm{e}_{(\mathrm{CB})}^{-} \\
& \mathrm{O}_{2(\mathrm{ads})}+\mathrm{e}_{(\mathrm{CB})}^{-} \rightarrow \mathrm{O}_{2}^{-} \\
& \mathrm{O}_{2}^{-}+\mathrm{H}^{+} \longrightarrow \mathrm{HO}_{2} \bullet \\
& \mathrm{HO}_{2}^{\bullet}+\mathrm{HO}_{2}^{\bullet}+\mathrm{H}_{2} \mathrm{O}_{2}+\mathrm{O}_{2} \\
& \mathrm{H}_{2} \mathrm{O}_{2(\text { ads })}+\mathrm{e}_{(\mathrm{CB})}^{-} \rightarrow \cdot \mathrm{OH}+\mathrm{OH}^{-}
\end{aligned}
$$




$$
\begin{aligned}
& \mathrm{h}^{+}(\mathrm{VB})+\mathrm{H}_{2} \mathrm{O}_{(\mathrm{ads})} \rightarrow \bullet \mathrm{OH}+\mathrm{OH}^{+} \\
& \left.\mathrm{h}^{+}(\mathrm{VB})+\mathrm{OH}_{(\mathrm{ads})}^{-}\right) \rightarrow \bullet \mathrm{OH}
\end{aligned}
$$

At the beginning of the photocatalytic process, the ROS photogenerated have as main target the microorganism cell wall, destroying the lipopolysaccharide and peptidoglycan layers of the cell wall via lipid peroxidation and oxidation of the protein $[99,100,114]$. It is important to point out that hole $\left(\mathrm{h}^{+}\right)$not only participates in the formation of ROS but also competes directly in the oxidation of the lipopolysaccharide layers of the constituent structures of the cell membrane through the direct interaction of the $\mathrm{Ag}_{3} \mathrm{PO}_{4}$ with the bacterial wall $[111,115]$. It's should be borne in mind that during the irradiation of light, due to its empirical nature, $\mathrm{Ag}_{3} \mathrm{PO}_{4}$ undergoes considerable photoreduction, forming $\mathrm{Ag}^{\mathrm{o}}$ NPs on its surface [116]. This photogenerated material can also be responsible for the biological response since the $\mathrm{Ag}^{\mathrm{O}} / \mathrm{Ag}^{+}$has been proven to be fixed on the cell membrane surface, perforating the layers and destroying the microorganism $[115,117]$.

\section{Conclusions}

Based on the antimicrobial properties obtained from strain assays $C$. albicans, $P$. aeruginosa and B. subtilis, we conclude that silver phosphate showed remarkable bactericidal activity when irradiated with WLEDs. The results indicated in according to the death curve and the kinetic constant $\left(\mathrm{K}_{\mathrm{d}}\right)$ that the inhibitory effect of the $\mathrm{Ag}_{3} \mathrm{PO}_{4}$ under irradiation WLEDs is well pronounced to C. albicans in relation to P. augenosas and $B$. subitilis. It was demonstrated that in fungal cells ( $C$. albicans) there was total 
rupture suggesting the phenomenon of lipid peroxidation and protein oxidation caused by the presence of reactive oxygen species (ROS)/Ag generated during $\mathrm{Ag}_{3} \mathrm{PO}_{4}$ photoactivation and, consequently, causing cell wall permeability resulting in the leakage of cellular content that culminated in cell death. The photocatalyst $\mathrm{Ag}_{3} \mathrm{PO}_{4}$ also showed important sporicidal activity in B. subtilis as resistance with the consequent rupture of the endospore wall. However, the separation of the pure $\mathrm{Ag}_{3} \mathrm{PO}_{4}$ particles from the post-experiment solutions proved to be impractical.

\section{Acknowledgements}

This work was funded by the following grants - CNPq (307559/2016-8, 305757/2018$0)$. The authors also wish to acknowledge financial support from the CAPES Institution.

\section{Declarations of interest}

The authors declare that they have not conflict of interest to this work.

\section{References}

1. M. A. Montgomery and M. Elimelech, Environ. Sci. Technol. 41, 17 (2007).

2. K. Hodges and R. Gill, Gut Microbes 1, 4 (2010).

3. S. R. Moore, N. L. Lima, A. M. Soares, R. B. Oriá, R. C. Pinkerton, L. J. Barrett, R. L. Guerrant, and A. A. M. Lima, Gastroenterology 139, 1156 (2010).

4. M. Kosek, C. Bern, and R. L. Guerrant, Bull. World Health Organ. 81, 197 (2003).

5. M. Li, L. Zhu, and D. Lin, Environ. Sci. Technol. 45, 1977 (2011).

6. W. A. Petri Jr, M. Miller, H. J. Binder, M. M. Levine, R. Dillingham, and R. L. Guerrant, J. Clin. Invest. 118, 1277 (2008).

7. S. Merel, D. Walker, R. Chicana, S. Snyder, E. Baurès, and O. Thomas, Environ. Int. 59, 303 (2013). 
8. G. Zhang, Y. C. Zhang, M. Nadagouda, C. Han, K. O'Shea, S. M. El-Sheikh, A. A. Ismail, and D. D. Dionysiou, Appl. Catal. B Environ. 144, 614 (2014).

9. L. X. Pinho, J. Azevedo, S. M. Miranda, J. Ângelo, A. Mendes, V. J. P. Vilar, V. Vasconcelos, and R. A. R. Boaventura, Chem. Eng. J. 266, 100 (2015).

10. D. R. de Figueiredo, U. M. Azeiteiro, S. M. Esteves, F. J. M. Gonçalves, and M. J. Pereira, Ecotoxicol. Environ. Saf. 59, 151 (2004).

11. W. W. Carmichael, J. Appl. Bacteriol. 72, 445 (1992).

12. G. A. Codd, L. F. Morrison, and J. S. Metcalf, Toxicol. Appl. Pharmacol. 203, 264 (2005).

13. R. Nishiwaki-Matsushima, T. Ohta, S. Nishiwaki, M. Suganuma, K. Kohyama, T. Ishikawa, W. W. Carmichael, and H. Fujiki, J. Cancer Res. Clin. Oncol. 118, 420 (1992).

14. L. F. Caslake, D. J. Connolly, V. Menon, C. M. Duncanson, R. Rojas, and J. Tavakoli, Appl. Environ. Microbiol. 70, 1145 (2004).

15. W. Wang, G. Huang, J. C. Yu, and P. K. Wong, J. Environ. Sci. 34, 232 (2015).

16. F. B. Daniel, L. W. Condie, M. Robinson, J. A. Stober, R. G. York, G. R. Olson, and S.-R. Wang, J. AWWA 82, 61 (1990).

17. G. A. Boorman, V. Dellarco, J. K. Dunnick, R. E. Chapin, S. Hunter, F. Hauchman, H. Gardner, M. Cox, and R. C. Sills, Environ. Health Perspect. 107, 207 (1999).

18. T. A. Bellar, J. J. Lichtenberg, and R. C. Kroner, J. Am. Water Works Assoc. 66, 703 (1974).

19. M. J. Nieuwenhuijsen, M. B. Toledano, N. E. Eaton, J. Fawell, and P. Elliott, Occup. Environ. Med. 57, 73 LP (2000).

20. J. K. Dunnick and R. L. Melnick, JNCI J. Natl. Cancer Inst. 85, 817 (1993).

21. F. Martínez, G. Calleja, J. A. Melero, and R. Molina, Appl. Catal. B Environ. 60, $181(2005)$.

22. E. Neyens and J. Baeyens, J. Hazard. Mater. 98, 33 (2003).

23. V. Kavitha and K. Palanivelu, Chemosphere 55, 1235 (2004).

24. I. A. Alaton, I. A. Balcioglu, and D. W. Bahnemann, Water Res. 36, 1143 (2002).

25. D. F. Laine and I. F. Cheng, Microchem. J. 85, 183 (2007).

26. C. Maria Magdalane, K. Kaviyarasu, N. Matinise, N. Mayedwa, N. Mongwaketsi,

D. Letsholathebe, G. T. Mola, N. AbdullahAl-Dhabi, M. V. Arasu, M. Henini, J. 
Kennedy, M. Maaza, and B. Jeyaraj, South African J. Chem. Eng. 26, 49 (2018).

27. C. M. Magdalane, K. Kaviyarasu, G. M. A. Priyadharsini, A. K. H. Bashir, N. Mayedwa, N. Matinise, A. B. Isaev, N. Abdullah Al-Dhabi, M. V. Arasu, S. Arokiyaraj, J. Kennedy, and M. Maaza, J. Mater. Res. Technol. 8, 2898 (2019).

28. K. Kaviyarasu, C. Maria Magdalane, D. Jayakumar, Y. Samson, A. K. H. Bashir, M. Maaza, D. Letsholathebe, A. H. Mahmoud, and J. Kennedy, J. King Saud Univ. - Sci. 32, 1516 (2020).

29. M. R. Assalin, E. Dos Santos Almeida, and N. Durán, Int. J. Environ. Res. Public Health 6, 1145 (2009).

30. W.-J. Huang, G.-C. Fang, and C.-C. Wang, Sci. Total Environ. 345, 261 (2005).

31. C.-P. Yu and Y.-H. Yu, Water Sci. Technol. 42, 435 (2000).

32. C. Sichel, J. Blanco, S. Malato, and P. Fernández-Ibáñez, J. Photochem. Photobiol. A Chem. 189, 239 (2007).

33. S. T. Summerfelt, Aquac. Eng. 28, 21 (2003).

34. L. B. Richardson, D. T. Burton, G. R. Helz, and J. C. Rhoderick, Water Res. 15, 1067 (1981).

35. S. K. Alharbi, J. Kang, L. D. Nghiem, J. P. van de Merwe, F. D. L. Leusch, and W. E. Price, Process Saf. Environ. Prot. 112, 222 (2017).

36. D. Haaken, T. Dittmar, V. Schmalz, and E. Worch, Water Res. 52, 20 (2014).

37. C. Jungfer, T. Schwartz, and U. Obst, Water Res. 41, 188 (2007).

38. Y.-H. Hsueh, K.-S. Lin, W.-J. Ke, C.-T. Hsieh, C.-L. Chiang, D.-Y. Tzou, and S.-T. Liu, PLoS One 10, e0144306 (2015).

39. R. Kumar, A. Umar, G. Kumar, and H. S. Nalwa, Ceram. Int. 43, 3940 (2017).

40. M. Amiri, Z. Etemadifar, A. Daneshkazemi, and M. Nateghi, J. Dent. Biomater. 4, 347 (2017).

41. U. L. N. H. Senarathna, S. S. N. Fernando, T. D. C. P. Gunasekara, M. M. Weerasekera, H. G. S. P. Hewageegana, N. D. H. Arachchi, H. D. Siriwardena, and P. M. Jayaweera, Chem. Cent. J. 11, 7 (2017).

42. J. J. Buckley, A. F. Lee, L. Olivi, and K. Wilson, J. Mater. Chem. 20, 8056 (2010). 43. J. A. Ibáñez, M. I. Litter, and R. A. Pizarro, J. Photochem. Photobiol. A Chem. 157, 81 (2003).

44. Y. Li, W. Zhang, J. Niu, and Y. Chen, ACS Nano 6, 5164 (2012). 
45. T. Matsunaga, R. Tomoda, T. Nakajima, and H. Wake, FEMS Microbiol. Lett. 29, $211(1985)$.

46. M. Tadashi, T. Ryozo, N. Toshiaki, and W. Hitoshi, FEMS Microbiol. Lett. 29, 211 (2018).

47. P.-C. Maness, S. Smolinski, D. M. Blake, Z. Huang, E. J. Wolfrum, and W. A. Jacoby, Appl. Environ. Microbiol. 65, 4094 LP (1999).

48. Y. Kikuchi, K. Sunada, T. Iyoda, K. Hashimoto, and A. Fujishima, J. Photochem. Photobiol. A Chem. 106, 51 (1997).

49. S. Elingarami, M. Liu, J. Fan, and N. He, J. Nanosci. Nanotechnol. 14, 932 (n.d.). 50. S. M. Dizaj, F. Lotfipour, M. Barzegar-Jalali, M. H. Zarrintan, and K. Adibkia, Mater. Sci. Eng. C 44, 278 (2014).

51. M. Bhamidipati and L. Fabris, Bioconjug. Chem. 28, 449 (2017).

52. S. Podder, D. Chanda, A. K. Mukhopadhyay, A. De, B. Das, A. Samanta, J. G. Hardy, and C. K. Ghosh, Inorg. Chem. 57, 12727 (2018).

53. M. A. Saidani, A. Fkiri, and L.-S. Smiri, J. Inorg. Organomet. Polym. Mater. 29, 710 (2019).

54. A. Bassegoda, K. Ivanova, E. Ramon, and T. Tzanov, Appl. Microbiol. Biotechnol. 102, 2075 (2018).

55. J. J. Liu, X. L. Fu, S. F. Chen, and Y. F. Zhu, Appl. Phys. Lett. 99, 191903 (2011).

56. U. Sulaeman, F. Febiyanto, S. Yin, and T. Sato, Catal. Commun. 85, 22 (2016).

57. Y. Bi, S. Ouyang, N. Umezawa, J. Cao, and J. Ye, J. Am. Chem. Soc. 133, 6490 (2011).

58. X. Ma, B. Lu, D. Li, R. Shi, C. Pan, and Y. Zhu, J. Phys. Chem. C 115, 4680 (2011)

59. G.-F. Huang, Z.-L. Ma, W.-Q. Huang, Y. Tian, C. Jiao, Z.-M. Yang, Z. Wan, and A. Pan, J. Nanomater. 2013, 371356 (2013).

60. P. Amornpitoksuk, K. Intarasuwan, S. Suwanboon, and J. Baltrusaitis, Ind. Eng. Chem. Res. 52, 17369 (2013).

61. G. Botelho, J. C. Sczancoski, J. Andres, L. Gracia, and E. Longo, J. Phys. Chem. C 119, 6293 (2015).

62. T. M. S. Costa, M. S. Lima, J. F. Cruz Filho, L. J. Silva, R. S. Santos, and G. E. Luz, J. Photochem. Photobiol. A Chem. 364, (2018). 
63. A. Wu, C. Tian, W. Chang, Y. Hong, Q. Zhang, Y. Qu, and H. Fu, Mater. Res. Bull. 48, 3043 (2013).

64. X. Hong, M. Li, S. Shan, K. S. Hui, M. Mo, and X. Yuan, Environ. Sci. Pollut. Res. 23, 13458 (2016).

65. Y. Seo, B.-E. Yeo, Y.-S. Cho, H. Park, C. Kwon, and Y.-D. Huh, Mater. Lett. 197, 146 (2017).

66. L. Baldino, J. Aragón, G. Mendoza, S. Irusta, S. Cardea, and E. Reverchon, J. Chem. Technol. Biotechnol. 94, 98 (2019).

67. X. Yan, Q. Gao, J. Qin, X. Yang, Y. Li, and H. Tang, Ceram. Int. 39, 9715 (2013).

68. D. J. Martin, N. Umezawa, X. Chen, J. Ye, and J. Tang, Energy Environ. Sci. 6, 3380 (2013).

69. P. Dong, Y. Wang, H. Li, H. Li, X. Ma, and L. Han, J. Mater. Chem. A 1, 4651 (2013).

70. K. P. Steckiewicz, J. Zwara, M. Jaskiewicz, S. Kowalski, W. Kamysz, A. ZaleskaMedynska, and I. Inkielewicz-Stepniak, Oxid. Med. Cell. Longev. 2019, 6740325 (2019).

71. H. Xu, H. Li, J. Xia, S. Yin, Z. Luo, L. Liu, and L. Xu, ACS Appl. Mater. Interfaces 3, 22 (2011).

72. X. Guan, J. Shi, and L. Guo, Int. J. Hydrogen Energy 38, 11870 (2013).

73. R. Chong, X. Cheng, B. Wang, D. Li, Z. Chang, and L. Zhang, Int. J. Hydrogen Energy 41, 2575 (2016).

74. Y. Liu, L. Fang, H. Lu, L. Liu, H. Wang, and C. Hu, Catal. Commun. 17, 200 (2012).

75. P. Wang, B. Huang, X. Qin, X. Zhang, Y. Dai, J. Wei, and M.-H. Whangbo, Angew. Chemie Int. Ed. 47, 7931 (2008).

76. H. Wang, L. He, L. Wang, P. Hu, L. Guo, X. Han, and J. Li, CrystEngComm 14, 8342 (2012).

77. Y. Xie, Z. Huang, Z. Zhang, X. Zhang, R. Wen, Y. Liu, M. Fang, and X. Wu, Appl. Surf. Sci. 389, 56 (2016).

78. M. Rakibuddin and R. Ananthakrishnan, New J. Chem. 40, 3385 (2016).

79. C.-T. Dinh, T.-D. Nguyen, F. Kleitz, and T.-O. Do, Chem. Commun. 47, 7797 (2011).

80. K. Huang, Y. Lv, W. Zhang, S. Sun, B. Yang, F. Chi, S. Ran, and X. Liu, Mater. 
Res. 18, 939 (2015).

81. J. F. Cruz-Filho, T. M. S. Costa, M. S. Lima, L. J. Silva, R. S. Santos, L. S. Cavalcante, E. Longo, and G. E. Luz, J. Photochem. Photobiol. A Chem. 377, 14 (2019).

82. A. Prasad, L. Du, M. Zubair, S. Subedi, A. Ullah, and M. S. Roopesh, Food Eng. Rev. 12, 268 (2020).

83. P. Ganguly, C. Byrne, A. Breen, and S. C. Pillai, Appl. Catal. B Environ. 225, 51 (2018).

84. S. Nakamura, Jpn. J. Appl. Phys. 30, L1705 (1991).

85. S. Nakamura, S. Pearton, and G. Fasol, Meas. Sci. Technol. 12, 755 (2001).

86. C. Casado, R. Timmers, A. Sergejevs, C. T. Clarke, D. W. E. Allsopp, C. R. Bowen, R. van Grieken, and J. Marugán, Chem. Eng. J. 327, 1043 (2017).

87. W.-K. Jo and R. J. Tayade, Ind. Eng. Chem. Res. 53, 2073 (2014).

88. S. Singh, in Handb. Light Emit. Schottky Diode Res. (2009).

89. R. A. Roca, J. C. Sczancoski, I. C. Nogueira, M. T. Fabbro, H. C. Alves, L. Gracia, L. P. S. Santos, C. P. de Sousa, J. Andrés, G. E. Luz, E. Longo, and L. S. Cavalcante, Catal. Sci. Technol. 5, 4091 (2015).

90. W. A. M. Hijnen, E. F. Beerendonk, and G. J. Medema, Water Res. 40, 3 (2006).

91. P. G. Mazzola, A. M. Da Silva Martins, and T. C. Vessoni Penna, Brazilian J. Microbiol. 34, 33 (2003).

92. A. Mai-Prochnow, M. Clauson, J. Hong, and A. B. Murphy, Sci. Rep. 6, 38610 (2016).

93. J. P. Ruparelia, A. K. Chatterjee, S. P. Duttagupta, and S. Mukherji, Acta Biomater. 4, 707 (2008).

94. A. Casolari, Microbial Death (2018).

95. S. Agnihotri, S. Mukherji, and S. Mukherji, RSC Adv. 4, 3974 (2014).

96. A. Arora, T. M. Byrem, M. G. Nair, and G. M. Strasburg, Arch. Biochem. Biophys. 373, 102 (2000).

97. M. Sharma, H. Bansal, and P. K. Gupta, Indian J. Exp. Biol. 40, 252 (2002).

98. M. E. Steinmann, A. González-Salgado, P. Bütikofer, P. Mäser, and E. Sigel, FASEB J. 29, 3228 (2015). 
99. V. Mailänder and K. Landfester, Biomacromolecules 10, 2379 (2009).

100. W. Jiang, B. Y. S. Kim, J. T. Rutka, and W. C. W. Chan, Nat. Nanotechnol. 3, 145 (2008).

101. H. Zhu, H. Jin, J. Pi, H. Bai, F. Yang, C. Wu, J. Jiang, and J. Cai, Scanning 38, 322 (2016).

102. D. Bolintineanu, E. Hazrati, H. T. Davis, R. I. Lehrer, and Y. N. Kaznessis, Peptides 31, 1 (2010).

103. Z.-Q. Xiong, X.-R. Tu, S.-J. Wei, L. Huang, X.-H. Li, H. Lu, and G.-Q. Tu, PLoS One 8, e73884 (2013).

104. I. Matai, A. Sachdev, P. Dubey, S. Uday Kumar, B. Bhushan, and P. Gopinath, Colloids Surfaces B Biointerfaces 115, 359 (2014).

105. P. Setlow, J. Appl. Microbiol. 101, 514 (2006).

106. G. Alderton and N. Snell, Appl. Microbiol. 17, 745 LP (1969).

107. E. Berlin, H. R. Curran, and M. J. Pallansch, J. Bacteriol. 86, 1030 LP (1963).

108. Z. Yi, J. Ye, N. Kikugawa, T. Kako, S. Ouyang, H. Stuart-Williams, H. Yang, J. Cao, W. Luo, Z. Li, Y. Liu, and R. L. Withers, Nat. Mater. 9, 559 (2010).

109. Y. Chai, L. Wang, J. Ren, and W.-L. Dai, Appl. Surf. Sci. 324, 212 (2015).

110. I. TatlIdil, M. Sökmen, C. Breen, F. Clegg, C. K. Buruk, and E. BacaksIz, J. SolGel Sci. Technol. 60, 23 (2011).

111. W. Wang, B. Cheng, J. Yu, and G. Liu, Chem. Asian J. 7, 1902 (2012).

112. J. Ma, Q. Liu, L. Zhu, J. Zou, K. Wang, M. Yang, and S. Komarneni, Appl. Catal. B Environ. 182, 26 (2016).

113. J. Ren, Y. Chai, Q. Liu, L. Zhang, and W. Dai, Appl. Surf. Sci. 403, 177 (2017).

114. C. R. Rajith Kumar, V. S. Betageri, G. Nagaraju, G. H. Pujar, H. S. Onkarappa, and M. S. Latha, J. Inorg. Organomet. Polym. Mater. 30, 3410 (2020).

115. A. Aarthi, M. Umadevi, R. Parimaladevi, G. V Sathe, S. Arumugam, and P. Sivaprakash, J. Inorg. Organomet. Polym. Mater. (2020).

116. T. M. S. Costa, M. S. Lima, J. F. Cruz Filho, L. J. Silva, R. S. Santos, and G. E. Luz, J. Photochem. Photobiol. A Chem. 364, 461 (2018).

117. A. Hamad, K. S. Khashan, and A. Hadi, J. Inorg. Organomet. Polym. Mater. 30, 4811 (2020). 



\section{Figure Captions}

Fig. 1. Inactivation effect of $\mathrm{Ag}_{3} \mathrm{PO}_{4}$ photocatalytic $\left(1 \mathrm{mg} \mathrm{mL}^{-1}\right)$ on (a) C. albicans, (b) P. aeruginosa and (c) B. subitilis.

Fig. 2. Kinetic constants on (a) C. albicans, (b) B. subitilis and (c) P. aeruginosa.

Fig. 3. Micrography of the C. albicans in different times of photocatalytic inactivation test: $0 \mathrm{~min}(\mathrm{a}), 10 \mathrm{~min}$ (b), $60 \mathrm{~min}$ (c), $120 \mathrm{~min}$ (d), and extravasation of the cytoplasmic content at $120 \mathrm{~m}$. In insert: cell structure in the form of an elliptic and deteriorated cell wall.

Fig. 4. Infogram of the size variation and morphology of the cells $C$. Albicans (a) and size distribution of its vegetative forms during the photocatalytic process (b). and (b).

Fig. 5. Micrography of the B. Subtilis in different times of photocatalytic inactivation test: 0 min (a), $10 \min (b), 20 \min (c)$ and $120 \min (d)$. 
Figures
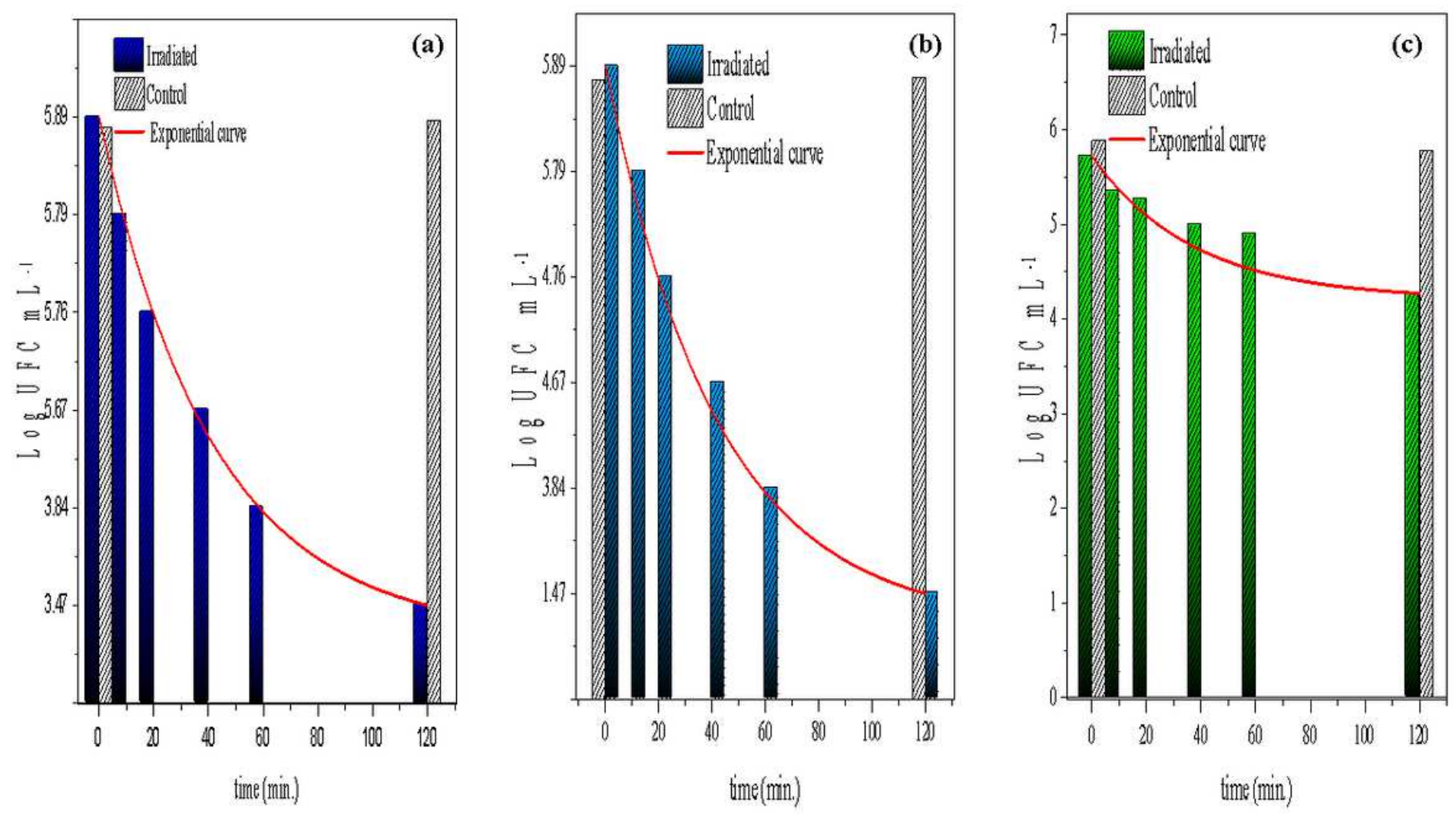

Figure 1

Inactivation effect of Ag3PO4 photocatalytic (1mg mL-1) on (a) C. albicans, (b) P. aeruginosa and (c) B. subitilis. 

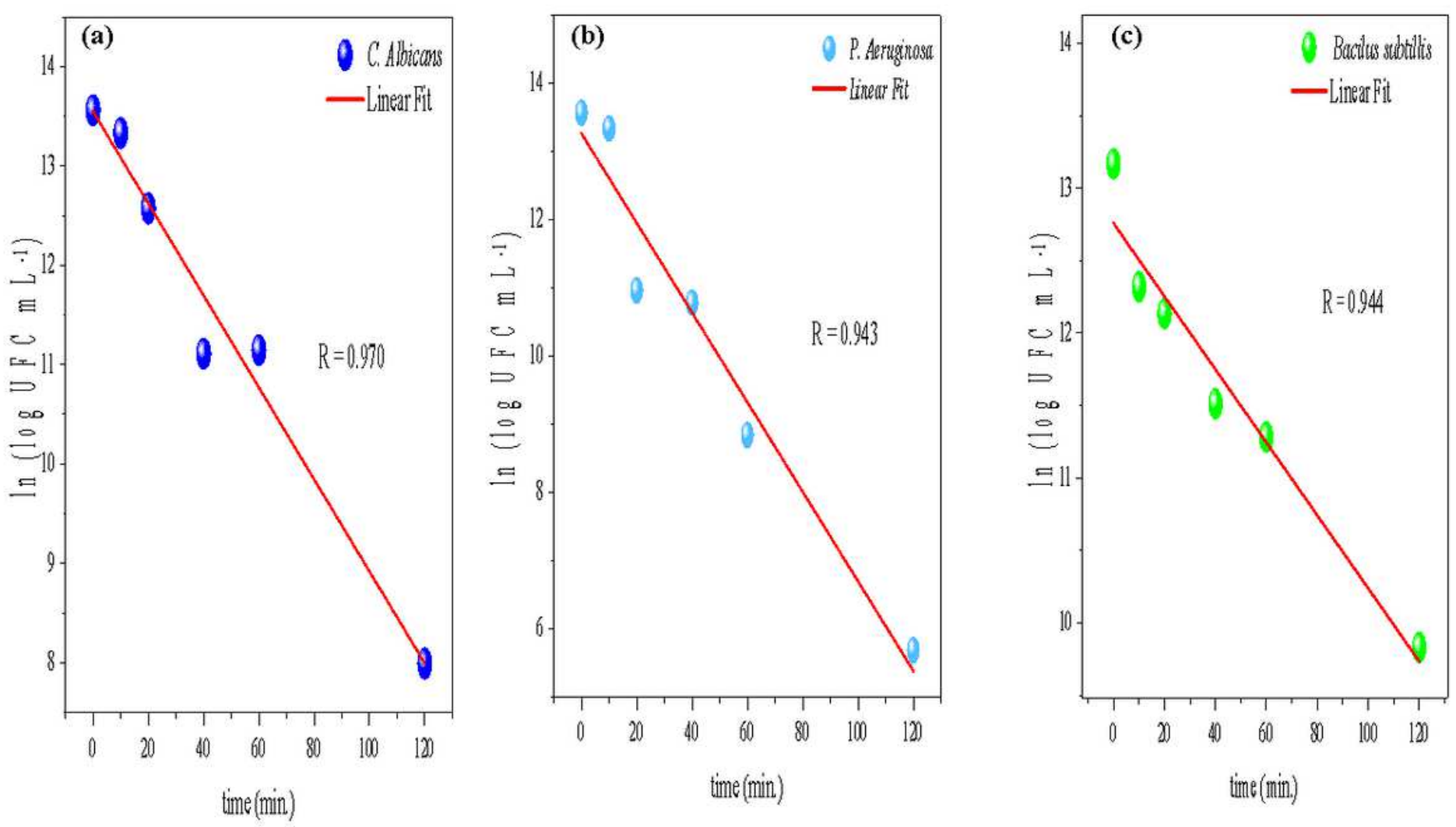

Figure 2

Kinetic constants on (a) C. albicans, (b) B. subitilis and (c) P. aeruginosa.

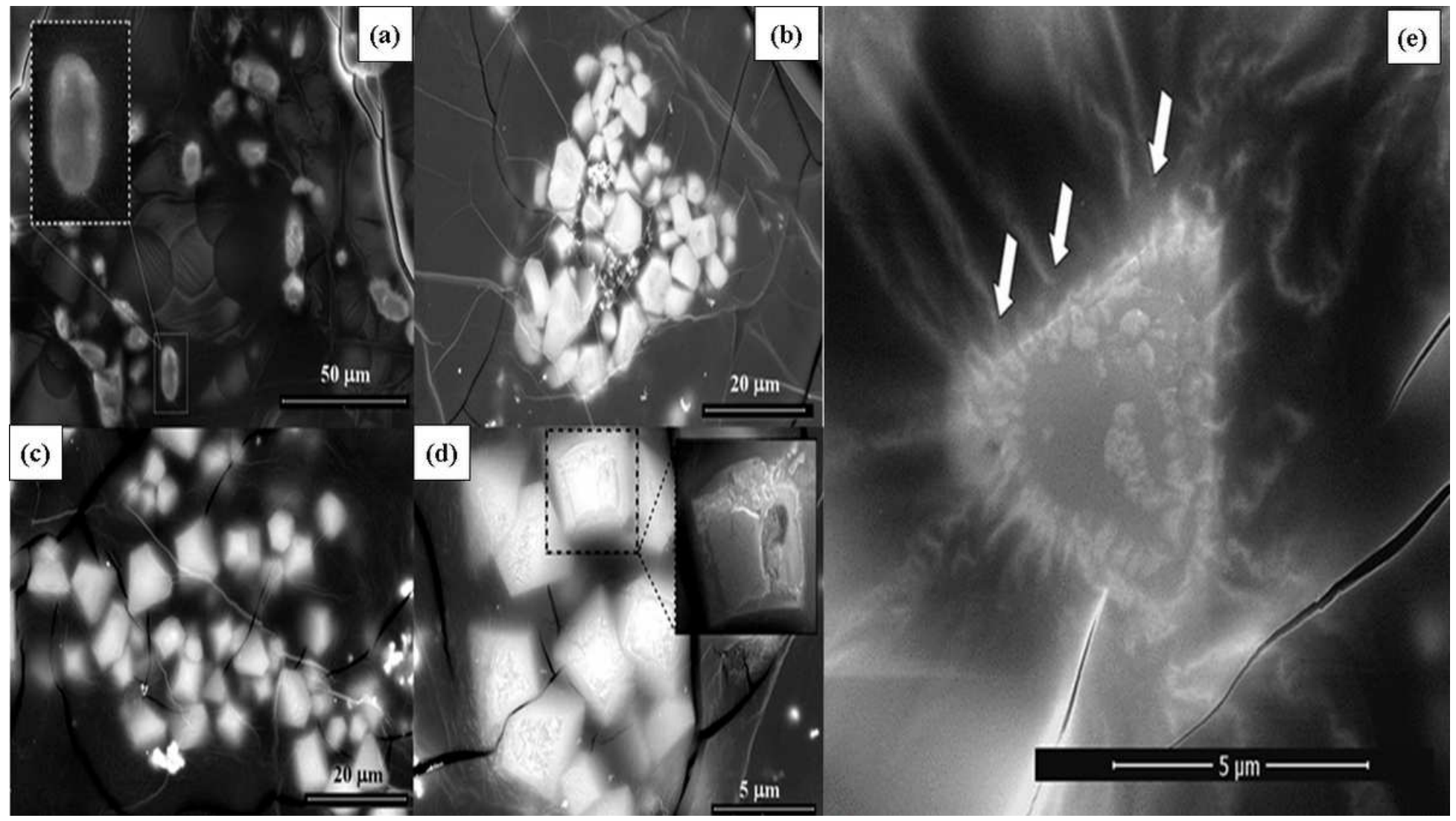




\section{Figure 3}

Micrography of the C. albicans in different times of photocatalytic inactivation test: 0 min (a), 10 min (b), $60 \mathrm{~min}$ (c), $120 \mathrm{~min}$ (d), and extravasation of the cytoplasmic content at $120 \mathrm{~m}$. In insert: cell structure in the form of an elliptic and deteriorated cell wall.

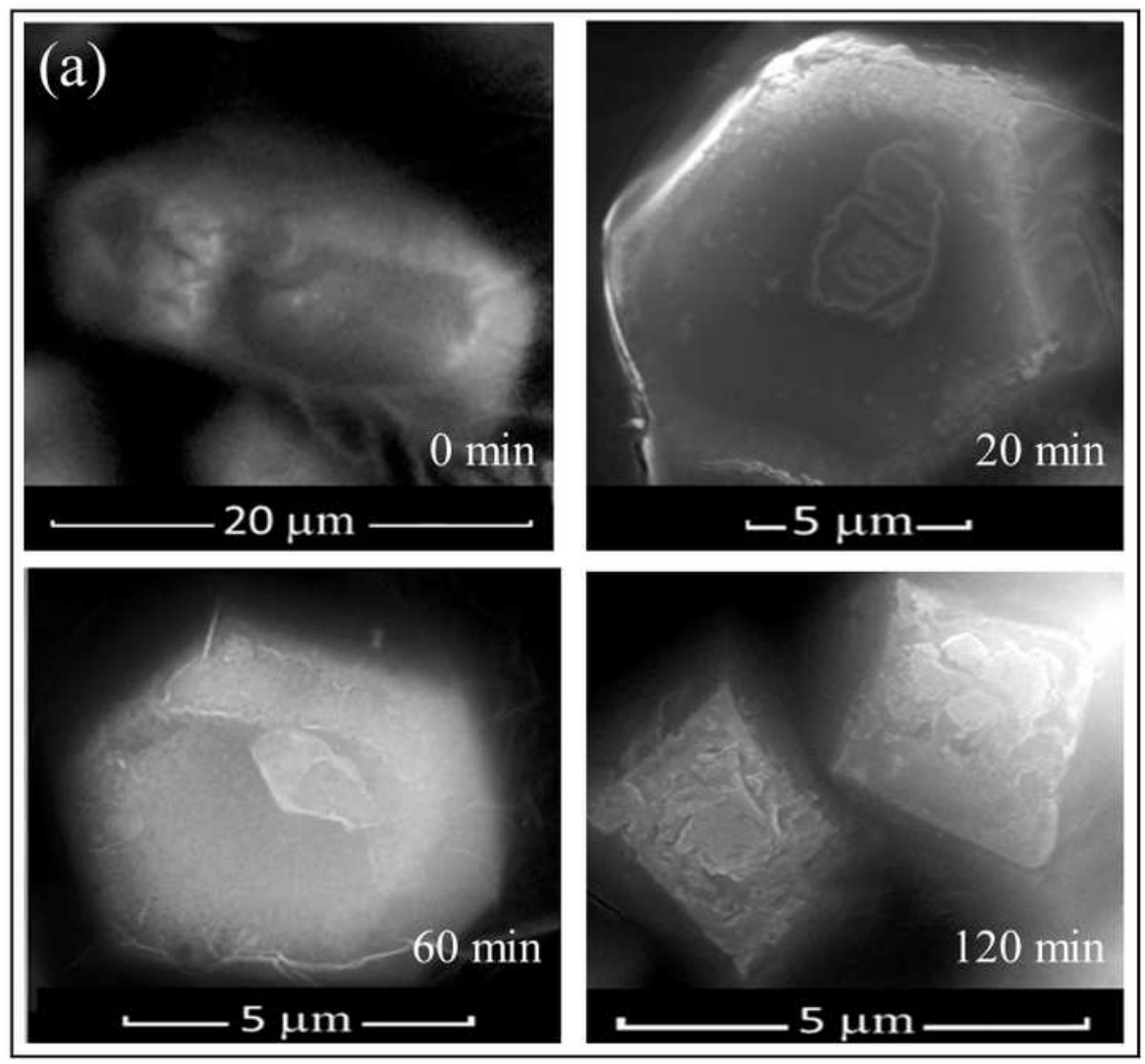

(b)

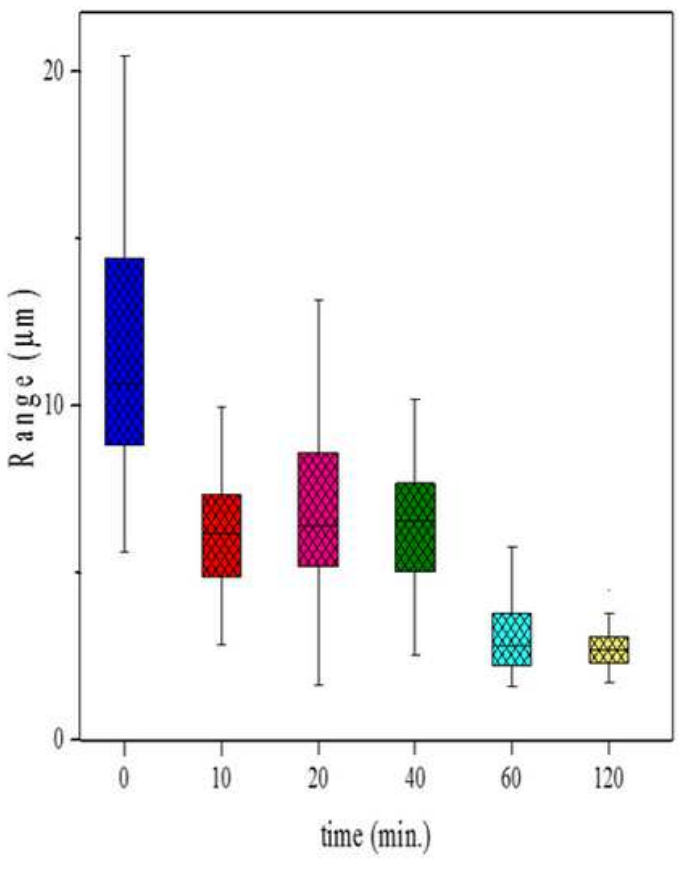

Figure 4

Infogram of the size variation and morphology of the cells C. Albicans (a) and size distribution of its vegetative forms during the photocatalytic process (b). and (b). 


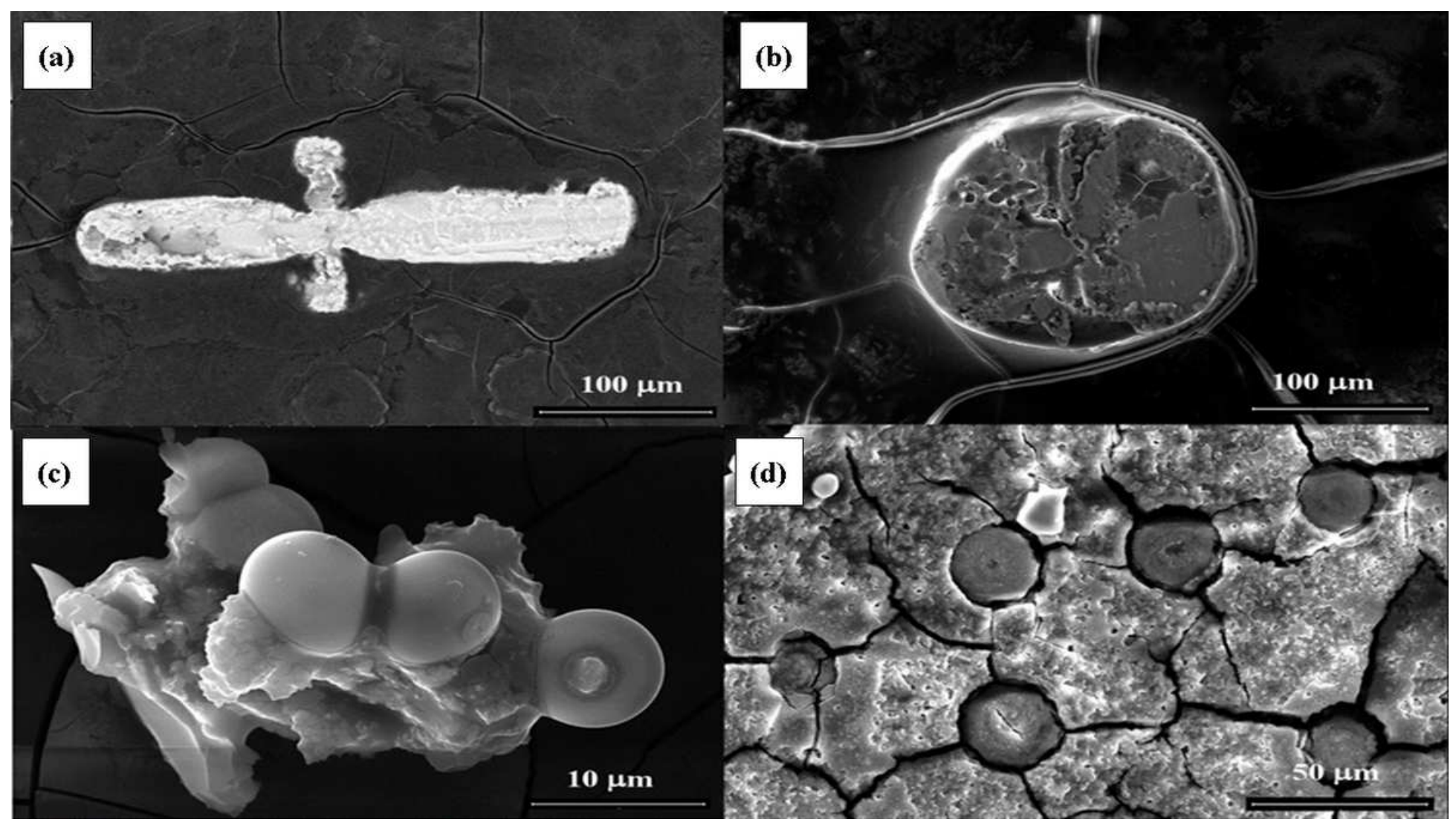

\section{Figure 5}

Micrography of the B. Subtilis in different times of photocatalytic inactivation test: 0 min (a), 10 min (b), $20 \mathrm{~min}(\mathrm{c})$ and $120 \mathrm{~min}(\mathrm{~d})$. 